\title{
Tactical Evacuation of Casualties by Military Helicopters: Present and Future Aspects
}

\author{
Aytekin Ünlü, M Fatih Can, Gokhan Yagci, Ismail Ozerhan, Juan A Asensio, Patrizio Petrone
}

\begin{abstract}
Injury is a surgical disease, and survival is inversely proportionate to elapsed time to treatment. As the routine use of helicopters started during the Vietnam War, it has been well-established that rapid transport was associated with unprecedented survival of critically injured patients. Currently, helicopters are used for tactical and medical evacuation purposes both in the Turkish Military and civilian health care system. Despite the rapid transport advantages, these flying ambulances are austere environments in terms of limited space and medical resources. Accordingly, a study group consisting of experienced military trauma surgeons has analyzed the data related with the present and future aspects of casualty evacuation missions with military helicopters.

The main focus of this study was to increase the Turkish Trauma Society awareness, improve en route care quality, identify new research topics and increase military medical readiness for the ensuing conflicts and disaster situations.
\end{abstract}

Keywords: Trauma, Prehospital care, Evacuation, Helicopter.

How to cite this article: Ünlü A, Can MF, Yagci G, Ozerhan I, Asensio JA, Petrone P. Tactical Evacuation of Casualties by Military Helicopters: Present and Future Aspects. Panam J Trauma Critical Care Emerg Surg 2013;2(2):83-88.

Source of support: Nil

Conflict of interest: None declared

\section{RESUMEN}

El trauma es una enfermedad quirúrgica y la sobrevida es inversamente proporcional al tiempo transcurrido para su tratamiento. La utilización rutinaria de helicópteros comenzó durante la Guerra de Vietnam, asociándose la sobrevida sin precedentes hasta ese momento al transporte rápido de pacientes críticamente lesionados. Actualmente, los helicópteros son utilizados para propósitos tácticos y para evacuación médica tanto por el Ejército Turco como en el sistema de salud civil. A pesar de su ventaja para el transporte rápido de víctimas, estas ambulancias aéreas poseen características austeras en cuanto al espacio limitado y de recursos médicos. Basado en ello, un grupo constituido por cirujanos de trauma militares con experiencia, han realizado un estudio analizando información relacionada con el presente y el futuro de las misiones de evacuación de heridos utilizando helicópteros militares.

El objetivo principal de este estudio es incrementar la concientización de la Sociedad de Trauma de Turquía en mejorar la calidad de cuidado en el transporte, identificar nuevos tópicos de investigación y aumentar el grado de preparación médica militar para situaciones de conflictos y desastres.

Palabras claves: Trauma, Cuidado pre-hospitalario, Evacuación, Helicóptero.

\section{INTRODUCTION}

Combat casualty evacuation started from a point where the chance for combat wounded soldiers was extremely low. The soldiers remained on the battlefield until the end of combat. Larrey, ${ }^{1}$ a chief surgeon in Napoleonic French Army developed horse driven carriages what he called 'The Flying Ambulances' for the rapid evacuation and treatment of the wounded soldier. He realized that delays in evacuation increased mortality and morbidity. Advances in military trauma care instigated by lessons learned at times of war have often led to their adoption by civilian trauma care providers.

With the development of more lethal weapons in the last century, such as precision artillery and machine guns, fighting troops had to be dispersed over more extended combat fields that increased evacuation times and mortality. So, mechanized ambulance had to be implemented. During the Korean War, helicopters appeared on the scene for the first time. The evolution of rapid transport by helicopters reached its highest level in the Vietnam War. ${ }^{2}$ During the Vietnam War, the survival rate in medical facilities was increased $2 \%$ over previous wars and the average time to definitive care was reduced from an average of 5 hours in the Korean War to only 1 hour. With the appearance of helicopters, besides its crucial role in decreasing combat related mortality, casualty load burden was eliminated which increased the flexibility of fighting troops. The ability to rapidly evacuate critically injured casualties backward to more robust and capable medical facilities alleviated the logistic burden of transporting medical care to the forward battle zone. Also, rapid access of casualties to a military trauma center helped improve the morale of fighting troops.

Although some civilian studies report contradictory results on the use of helicopters and their benefits associated with shortened prehospital transport time,,$^{3-7}$ helicopters equipped with medical capabilities are widely used to evacuate casualties in today's military conflicts and fight against terrorism, especially from difficult geographical areas.

Undeniably, trauma is a surgical disease and survival is inversely proportionate with the time to definitive care. ${ }^{8,9}$ Civilian prehospital trauma care leans upon adequate medical supplies, ambulance based relatively rapid evacuation to a nearby hospital, adequate number of providers, a stable and secure accident scene. These factors are all inverted on the battlefield where a single medic or paramedic with limited supplies is present to care for numerous casualties in a hostile or austere environment. Casualty is the focus of mission for the civilian medic, but for the military personnel, the mission 
is the military objective which has to be accomplished despite casualties. Besides, in military settings, the treatment of casualties in a dynamic, rapidly evolving and hazardous combat environment is a real challenge for care givers and it may simply take hours to evacuate the casualties off the battlefield. ${ }^{10,11}$ Moreover, the urban legend of 'golden hour of shock' does not quite apply to combat trauma, and it has been suggested that the casualties only have 'a platinum 5 to 15 minutes' instead. ${ }^{12-16}$ The above data emphasize that in order to minimize preventable deaths it is required that an expeditious evacuation and uninterrupted prehospital care (tactical combat care and en route care) of the casualties, provided by the skilled military medical personnel expertized in austere environment, is established.

Turkish Military have performed tactical evacuation of more than 10,000 casualties in the last 20 years and act in concert with the civilian emergency medical system. The helicopters currently used for tactical missions, despite their indispensable role in maintaining the continuum of care, are typically austere environments which offer the care providers with limited space and supplies, that is to say 'what you take is all you have'.

\section{TACTICAL EVACUATION}

Care on the combat field is followed by tactical evacuation aiming to move stabilized but not necessarily stable patients. The highly unpredictable nature of terrorist acts renders this mission highly unplanned and requires the availability of 7/24 helicopter trauma team preparedness and rapid activation concurrently with the hospital trauma surgical team. On the contrary, medical evacuation (transport of the casualties that need a higher level or long term care) is rather planned and performed under more optimum (mechanically ventilated, fully monitorized, blood transfusion, infusion pump, etc.) conditions. The combat support hospital may provide additional helicopter teams to support multidirectional tactical evacuation missions while maintaining the core surgical capability. The personnel and medical logistic status of the hospital is a critical factor that requires a flexible organizational structure, practice and a highly conditioned team work.

Activation is triggered upon data transmission (number, mechanism and anatomic site of injury, severity of injury, physiological status) for the need to evacuate casualties. Information regarding the mechanism of injury is especially important as explosion victims are usually part of a mass casualty event and a group of casualties should be expected while gunshot wounds patients are more often injured in sporadic events and accepted to helicopters as individuals. Thus, the efficiency of en route care capability (specific equipment, maximum casualty load per helicopter) depends on continuous interventions to keep the casualties alive until the evacuation starts and the reliability of the initial data that triggers trauma team activation. Unfortunately, lack of reliable data from the combat settings still remains the primary issue for the prevention of trauma related deaths.

Tactical evacuation team is comprised of flight medicine certified, combat ready and highly trained medical personnel (a physician, and two paramedics) that take part in the daily surgical activities of the combat support hospital to maintain their skills. This team must perform their role as warfighters to assure crew and aircraft safety in a hostile environment. Explosives and loaded weapons with open safety mechanisms attached to casualty combat suits should be cautiously handled during physical examination by the medical crew.

\section{Tactical Evacuation Environment}

The military directives require the casualties be removed to a safer or cleared zone that is also convenient for helicopter landing. However, this also is not consistently possible and loading casualties under fire or in hover position or both may be practiced. Hence, provision of ballistic protection and combat equipment is also mandatory for medical personnel. The challenging aspect of en route care is its unique environment which is truly different from the emergency unit in a hospital. Sikorsky-S70 helicopter has a $6.7 \mathrm{~m}^{2}$ operational space (Fig. 1). The available operational space is much lower when the flight crew, medical personnel, medical and combat equipment attached to the casualties are considered.

Evacuation mission under low light situations has inconceivable effects on the tasks achieved by the medical personnel. ${ }^{17}$ This requires that all bright/white light sources be suppressed to avoid providing the enemy with a targeting

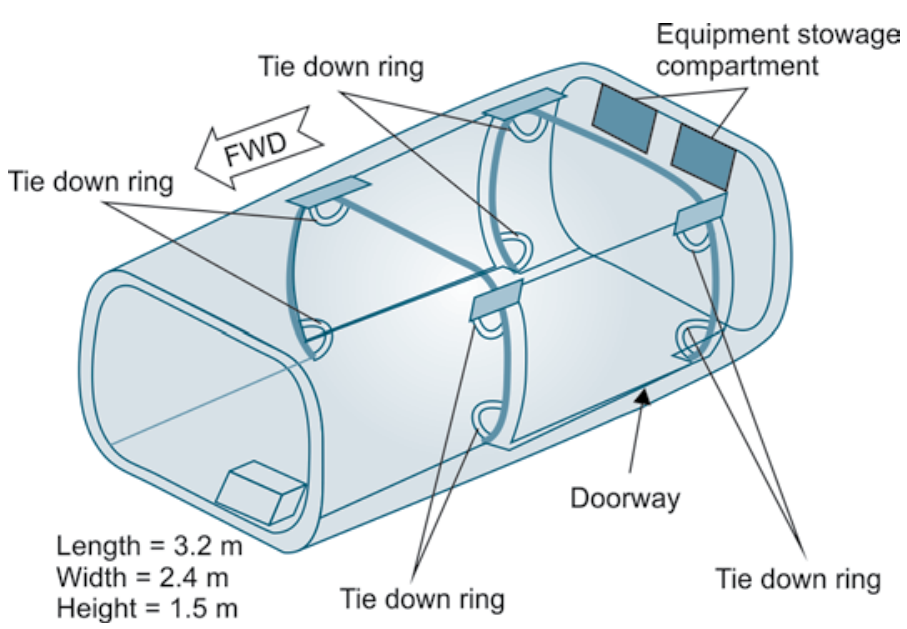

Fig. 1: Austere environment: depiction of Sikorsky (S-70) helicopter passenger compartment used for en route care 
source. Also, the ability to monitor and render en route care under minimal light conditions using subdued or red light sources further complicate the situation. Light discipline is also indispensable because the pilots using night vision systems may be blinded transiently by bright lights used for en route care. Subdued or red light sources hinder appropriate identification of blood (false brown or black color), skin color changes (cyanosis, burn), character of fluid discharge or wounds that could easily be confused with dirt.

The average ambient rotor noise level inside the cabin of S70 helicopter is well above greater than $85 \mathrm{~dB}$ and hearing protection is clearly needed. In this high noise environment, normal conversation and crew communication is a real challenge. Directing questions to the casualties and Glasgow Coma Scale analysis is usually hampered and a great deal of experience is required. The ability to detect monitor alarms or saturation monitors is negated. Medical crew member should always keep an eye on light alarms of monitors. Auscultation for physical examination is also impossible.

Vibration is another challenge for en route care. The performance of delicate lifesaving interventions, even an intravenous (IV) access, may be more difficult for inexperienced medical personnel. The helicopter tactical maneuvers to evade enemy fire or ground to air missile threat also complicate these lifesaving interventions.

The presence of highly skilled medical crew on board and shorter prehospital time interval may provide leverage for the above mentioned austere features (limited space and medical supplies, flight under fire or missile threat, unexpected number of casualty loading, higher combat related injury severity, etc.) of military helicopters. Thus, when compared with medical evacuation, the quality of en route care during tactical evacuation is notoriously suboptimal under given conditions.

\section{En Route Care}

The use of improvised explosive devices and a casualty surge has become the signature of terrorist acts both in military and civilian settings. ${ }^{18-23}$ Military helicopters are the first responders in the evacuation process from rural areas often confronting the first casualty surge. Hence, tactical evacuation should be considered not just as a rapid transport but also as a part of responses to mass-casualty incidents, especially when the site is remote or characterized by accessibility difficulties.

The philosophy of en route care is the prevention of prehospital 'care gap' and to decrease combat related preventable deaths. ${ }^{24}$ Once the casualties are loaded, quick assessment, helicopter triage and casualty prioritization, stabilization efforts and casualty data transmission are started concomitantly. The military directives state these actions be taken in the tactical field and repeated during the evacuation phase. During the quick assessment step, casualties are rapidly examined for life-threatening medical conditions (airway obstruction, respiratory failure, external bleeding) as stated by ATLS primary survey ${ }^{25}$ (Table 1).

\begin{tabular}{|l|}
\multicolumn{1}{|c|}{ Table 1: Primary survey } \\
\hline A-Airway \\
\hline B-Breathing \\
\hline C-Circulation \\
\hline D-Neurologic status \\
\hline E-Exposure/Environmental control \\
\hline
\end{tabular}

The stabilization step involves the determination of the adequacy of interventions on the tactical field (tourniquet, IV access and infusion rate, etc.) and efforts to improve these interventions (i.e. insertion of an additional IV catheter), awareness for possible missed and untreated injuries due to combat stress and continuous en route monitorization for sudden changes in casualty health status (Table 2).

Table 2: Actual en route medical capabilities

-Whole body physical examination

- Wound examination

- Determination of injury severity

- Control/reinforcement of local wound dressings

- IV/IM analgesic treatment

- Application of other medical treatments

- Tourniquet application/control

- Neurologic examination (GCS)

- Cardiopulmonary resuscitation

- Casualty monitorization (BP, HR, EKG, $\mathrm{SaO}_{2}$ )

- Prevention of hypothermia

- Needle thoracostomy (tension pneumothorax)

- Rapid pressure IV infusion (Belmont Instruments ${ }^{\circledR}$ )

- Oxygen administration

- ET tube insertion

- Suctioning of ET tubes or cavities

The overall goal of trauma triage is to match the most aggressive and available medical resources with the needs of the most seriously injured patients (appropriate triage) while minimizing unintentionally assigning a critically injured casualty as low priority (undertriage). Currently, most trauma triage tools are based on little data, ${ }^{26,27}$ result in poorly allocated resources,${ }^{28}$ fail to reliably discriminate patients benefiting from trauma center care whereas others can predict operating room (OR) use and emergent intensive care unit admission (e.g. hypotensive and gunshot as wounding mechanism) ${ }^{29,30}$ Prehospital triage of patients with trauma is routinely challenging, but more so in mass casualty situations, military operations and helicopter environment. Prioritization of casualties in the austere environment of military helicopters is a crucial step to 
focus on most critically traumatized casualty and to prevent inundation of already limited resources aboard. ${ }^{31,32}$ In our previous study ${ }^{31}$ we triaged 70 casualties during casualty evacuation and compared ACS, CRAMS and START triage tools. We found a statistically significant correlation between overall ISS levels and ACS and START triage tools $(\mathrm{p}<0.01)$. ACS triage system identified $85 \%$ of ISS $>15$ injuries and undertriaged 4 extremity vascular injuries. We concluded that triage of casualties during tactical evacuation is a feasible and useful adjunct of trauma care during transport.

Transmission of casualty data to the receiving combat support hospital is of critical importance. The data involving the mechanism of injury, triage code relevant to clinical status of each casualty and anatomic site of injury should be consistent and easily interpretable. The coded data of casualties received from multiple tactical evacuation routes gather at the command control center and assessed by medical personnel for the availability of sources and need for direct transport to a role 2 military medical facility (Fig. 2). This essential data has important implications for hospital organization and may affect patient care. The treatment of severely injured can be handled within the capabilities of the combat support hospital based on general surgeons and other surgical subspecialties. However, handling a multiple or mass casualty event requires a different organization. The sudden surge of patients creates a concurrent demand on resources that may cause bottlenecks, e.g. in operation rooms, diagnostic imaging, ICU and specialist staff, particularly in subspecialties. Data transmission decreases the time spent for casualty assessment upon admission at the hospital and enables hospital planning for life saving interventions both in the emergency service and operating room. ${ }^{32}$

\section{FUTURE ASPECTS}

By definition, the term mass casualty implies situations that involve large number of victims either with severe or unique

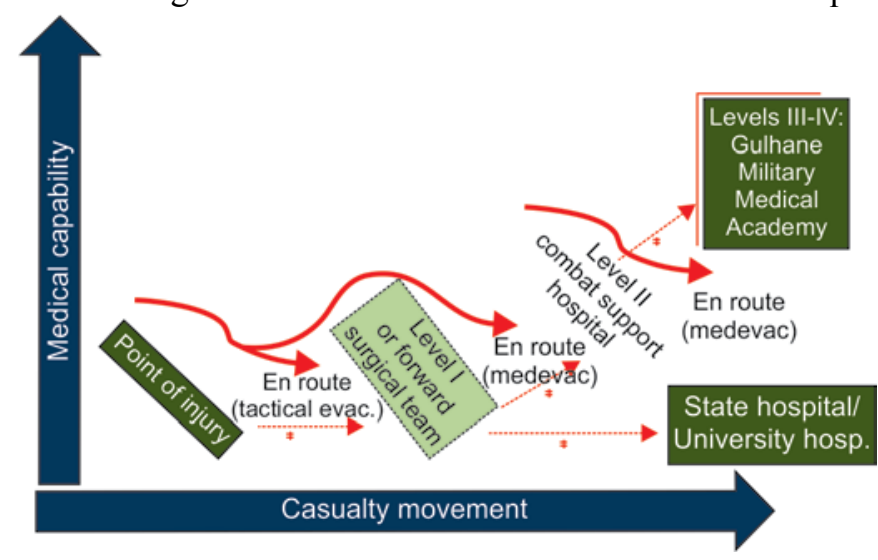

Fig. 2: Depiction of evacuation chain through echelons of care ( ${ }^{*}$ en route casualty Med. data transmission) injuries, overwhelming the responding medical resources substantially. ${ }^{19}$ In the literature, there are few reports of flight teams responding to single mass casualty incidents which are all characterized by rapid scene evacuation and efficient distribution to different trauma facilities. ${ }^{33-36}$ Unlike hospital settings, helicopters capable of medical care have much lower threshold for 'mass casualty incident'. Thus, further studies are needed to establish guidelines to improve en route care in mass casualty incidents.

Traditional monitors to measure vital signs are used in both civilian and military prehospital setting because of the wide availability of these systems, for quick assessment of casualty physiological status and stability. However, the physiological response to acute blood loss is a dynamic process and the current monitors may show normal vital signs although the patient needs an immediate life saving intervention or has a severe degree of tissue hypoperfusion. Studies demonstrate that young patients can lose up to $60 \%$ of total circulating blood volume and remain relatively asymptomatic. ${ }^{37}$ To improve outcomes by early identifying hemorrhage and circulatory collapse, more sensitive markers of acute hypoperfusion are needed for timely interventions. ${ }^{38}$ Addition of physiological parameters for early prediction (normal systolic blood pressure and Glasgow Coma Score) of ongoing blood loss and circulatory collapse to advanced, noninvasive monitors may significantly improve field triage and care in the combat and tactical evacuation environment. Some of these earlier and possibly more predictive indicators of hypovolemia include physiological variables like Shock Index, Pulse Pressure, Field Trauma Score, ECG R-wave amplitude and heart rate variability (HRV). ${ }^{38-42}$ HRV may represent an additional objective trauma triage tool. ${ }^{43-46}$ King et $\mathrm{al}^{42}$ demonstrated the usefulness of HRV as a prehospital trauma triage tool during helicopter transport to a level I trauma center which seemed to be better than any single standard traditional trauma triage criteria. They concluded that the integration of HRV technology to traditional monitors might improve overall prediction of severe injury and improve medical resource utilization in austere environments.

The future combat decision software will enable reliable real time data acquisition with a higher accuracy. The troops will be directed using automated software programs depending on wireless data transmission or the chief commander in the tactical operation room will be presented simplified choices to decide the fate of the combat. The data, inevitably will involve individual health data consisting of traditional vital signs and also parameters with a high predictive value of every soldier in a combat unit. From the commander's stand point the data is required to monitor the ongoing combat and decide what actions to be taken 
next. The military health care providers, however, focus on the number of incoming casualties, severity of injuries and steps to save more lives. Currently, military combat support hospitals already need the decision support technology for medical decision making for improved care and appropriate allocation of limited medical sources. At present, most trauma surgeons try to predict the injury severity by the landing speed of tactical evacuation helicopter. A recent advancement in this technology is WVSM (Athena, GTX Inc, Des Moines, IA) is a compact, patient worn wireless and/or wired monitor that measures, stores and transmits critical vital signs from point of injury to definitive treatment site. It eliminates the need to reevaluate casualties at each level of care addressing the specific needs of austere and chaotic environments from a combat zone to a mass casualty incident. ${ }^{45}$ Ryan et al ${ }^{46}$ also reported a soldier worn physiological status monitor developed as apart the vision mentioned above which enables remote triage of bleeding combat casualties. They concluded that providing accurate and reliable patient health status data could assist in the timely triage and evacuation. These improvements seem to adjust well to the austere environment of tactical evacuation using helicopters that provide uninterrupted reliable patient status data in every echelon of health care.

\section{CONCLUSION}

Helicopters are indispensable elements of evacuation chain in today's terrorist attacks and disasters like earthquakes affecting both the military and civilian society. Emphasis on prehospital combat casualty care may rise some questions on the readers mind. However, reasons become readily apparent when examining the common features between combat settings and emergency medical support for law enforcement, wilderness, and disaster medicine and in coping with the effects of weapons of mass destruction. Our reasons may also be justified by a simple review of newspaper headlines to determine what we have gone through over the last year. The aspects of tactical evacuation mentioned here is a summary of untold stories of many Turkish medical care providers that served for the military. We believe the lessons learned must be transmitted for the mutual benefit of civilian and military practice and for an integrated trauma system.

Helicopter tactical evacuation is not merely a rapid transport of trauma victims but an essential part of prehospital care. However, care is notoriously suboptimal especially when compared with medical evacuation. Upon analysis of available data, further prospective studies and additional funds are required to improve care given to both civilian and military trauma victims.

\section{REFERENCES}

1. Skandalakis PN, Lainas P, Odyseas Z, Skandalakis JE, Mirilas P. To afford the wounded speedy assistance: Dominique Jean Larrey and Napoleon. World J Surg 2006;30:1392-1399.

2. Mabry RL, De Lorenzo RA. Improving role of battlefield casualty care from point of injury to surgery. US Army Med Dep J 2011;2:87-91.

3. Cunningham P, Rutledge R, Backer CC, Clancy TV. A comparison of the association of helicopter and ground ambulance transport with the outcome of injury in trauma patients transported from the scene. J Trauma 1997;43:940-946.

4. Petri RW, Dyer A, Lumpkin J. The effect of prehospital transport time on the mortality from traumatic injury. Prehosp Disaster Med 1995;10:24-29.

5. Rutledge R. 9-1-1 access and trauma deaths: a complex association. Ann Emerg Med 1993;22:160-161.

6. Pepe PE, Wyatt CH, Bickell WH, Bailey ML, Mattox KL. The relationship between total prehospital time and outcome in hypotensive victims of penetrating injuries. Ann Emerg Med 1987;16:293-297.

7. McNabney WK. Vietnam in context. Ann Emerg Med 1981;10:659-661.

8. Gerhardt RT. Impact of emergency medicine specialists in tactical pre-hospital and en route care: what does the available data say? J Trauma 2007;62:S11-S12.

9. Salinas J, Nguyen R, Darrah MI, Kramer GA, Serio-Melvin ML. Advanced monitoring and decision support for battlefield critical care environment. US Army Med Dep J 2011;2:73-81.

10. Martinowitz U, Zaarur M, Yaron BL, Blumenfeld A, Martonovits G. Treating traumatic bleeding in a combat setting: possible role of recombinant activated factor VII. Mil Med 2004;169(12):S16-S18.

11. Beekley AC. United States military surgical response to modern large-scale conflicts: The ongoing evolution of a trauma system. Surg Clin N Am 2006;86:689-709.

12. Lerner EB, Moscati RM. The Golden Hour: Scientific fact or medical 'urban legend'? Acad Emerg Med 2001;8:758-760.

13. Gofrit ON, Leibouci D, Shapira SC. The trimodal death distribution of trauma victims: military experience from the Lebanon War. Mil Med 1997;162:24-26.

14. Bellamy RF. The causes of death in conventional land warfare: implications for combat casualty care research. Mil Med 1984;149:55-62.

15. Jay A. Maintaining the continuum of en route care. Crit Care Med 2008;36(7):S377-382.

16. Frykberg ER. Medical management of disasters and mass casualties from terrorist bombings: How can we cope? J Trauma 2002;53:201-212.

17. Gutierrez de Ceballos JP, Fuentes FT, Diaz P, Sanchez MS, Llorente CM, Sanz JE. Casualties treated at the closest hospital in the Madrid, March 11, terrorist bombings. Crit Care Med 2005;33(1):S107-112.

18. Aylwin CJ, König TC, Brennan NW, Shirley PJ, Davies G, Walsh MS, Brohi K. Reduction in critical mortality in urban mass casualty incidents: analysis of triage, surge, and resource use after the London bombings on July 7, 2005. Lancet 2006;368:2219-2225.

19. Peleg K, Aharonson-Daniel L, Stein M, Michaelson M, Kluger Y, Simon D, Noji EK. Gunshot and explosion injuries characteristics, outcomes, and implications for care of terrorrelated injuries in Israel. Ann Surg 2004;239:311-318. 
20. De Palma RG, Burris DG, Champion HR, Hodgson MJ. Current Concepts: blast injuries. N Engl J Med 2005;352:1335-1342.

21. Arnold JL, Halpern P, Tsai MC, Smithline H. Mass casualty terrorist bombings: a comparison of outcomes by bombing type. Ann Emerg Med 2004;43:263-273.

22. Gerhardt RT. Prehospital and emergency care research at the US Army Institute of Surgical Research: enabling the next great leap in combat casualty survival. US Army Med Dep J April-June 2011:82-86.

23. Advanced Trauma Life Support for Doctors. 8th ed. The ACS Committee on Trauma. Chicago, IL, 2008. p.2-24.

24. Tinkoff GH, O'Connor RE. Validation of new trauma triage rules for trauma attending response to the emergency department. J Trauma 2002;52:1153-1159.

25. Leach SR, Swor RA, Jackson RE, Fringer RC, Bonfiglio AX. Do outcome measures for trauma triage agree? Prehosp Emerg Care 2008;12:467-469.

26. Kann SH, Hougaard K, Christensen EF. Evaluation of pre-hospital trauma triage criteria: a prospective study at a Danish level I trauma centre. Acta Anaesthesiol Scand 2007;51:1172-1177.

27. Henry MC, Hollander JE, Alicandro JM, Cassara G, O'Malley $\mathrm{S}$, Thode HC Jr. Incremental benefit of individual American College of Surgeons trauma triage criteria. Acad Emerg Med 1996;3:992-1000.

28. Tiamfook-Morgan TO, Kociszewski C, Browne C, Barclay D, Wedel SK, Thomas SH. Helicopter scene response: regional variation in compliance with air medical triage guidelines. Prehosp Emerg Care 2008;12:443-450.

29. Einav S, Feigenberg Z, Weissman Charles, Zaichik Daniel, Caspi G, Kotler D, Freund HR. Evacuation priorities in mass casualty terror-related events: Implications for contingency planning. Ann Surg 2004;239:304-310.

30. Ünlu A, Durusu M, Arziman I, Eryilmaz M, Karsidag T, Petrone P, Asensio JA. Evacuation experiences with helicopter use as a part of trauma care. Balkan Military Medical Review 2010;13(4):157-161.

31. Ammon MA, Moore EE, Pons PT, et al. The role of regional trauma system in management of a mass disaster: an analysis of the Keystone, Colorado chairlift accident. J Trauma 1988;28:1468-1471.

32. Martin TE. The Ramstein air-show disaster. J R Army Med Corps 1990;136(1):19-26.

33. Maningas PA, Robinson M, Mallonee S. The EMS response to the Oklahoma City bombing. Prehospital Disast Med 1997;12(2):80-85.

34. Romundstad L, Sundnes KO, Pillgram-Larsen J, et al. Challenges of major incident management when excess resources are allocated: experiences from a mass casualty incident after roof collapse of a military command center. Prehospital Disast Med 2004;19(2):80-85.

35. Scalea TM, Maltz S, Yelon J, et al. Resuscitation of multiple trauma and head injury: role of crystalloid fluids and inotropes. Crit Care Med 1994;22:1610-1615.

36. Mabry R. McManus JG. Prehospital advances in the management of severe penetrating trauma. Crit Care Med 2008;36:S258-266.

37. Eastridge B, Salinas J, McManus JG, et al. Hypotension begins at $110 \mathrm{mmHg}$ : redefining 'hypotension' with data. J Trauma 2007;63:291-299.

38. Eastridge BJ, Butler F, Wade CE, Holcomb JB, Salinas J, Champion HR, Blackbourne LH. Field triage score (FTS) in battlefield casualties: validation of a novel triage technique in a combat environment. Am J Surg 2010;200(6):724-727.

39. Cooke WH, Salinas J, McManus JG, et al. Heart period variability in trauma patients may predict mortality and allow remote triage. Aviat Space Environ Med 2006;77:1107-1112.

40. McManus J, Convertino V, Cooke W, et al. R-wave amplitude in lead II of an electrocardiograph correlates with central hypovolemia in human beings. Acad Emerg Med 2006;13:10031010.

41. King DR, Ogilvie MP, Pereira BM, Chang Y, Manning RJ, Conner JA, Schulman CI, McKenney MG, Proctor KG. Heart rate variability as a triage tool in patients with trauma during prehospital helicopter transport. J Trauma 2009;67:436-440.

42. Cancio LC, Batchinsky AI, Salinas J, et al. Heart-rate complexity for prediction of prehospital lifesaving interventions in trauma patients. J Trauma 2008;65:813-819.

43. Batchinsky AI, Cancio LC, Salinas J, et al. Prehospital loss of $\mathrm{R}$-to-R interval complexity is associated with mortality in trauma patients. J Trauma 2007;63:512-518.

44. Proctor KG, Atapattu SA, Duncan RC. Heart rate variability index in trauma patients. J Trauma 2007;63:33-43.

45. Salinas J, Nguyen R, Darrah MI, Kramer GA, Serio-Melvin ML, Mann EA, Wolf SE, Chung KK, Renz EM, Cancio LC. Advanced monitoring and decision support for battlefield critical care environment. US Army Med Dep J 2011;2:73-81.

46. Ryan KL, Rickards CA, Hinojosa-Laborde C, Gerhardt RT, Cain J, Convertino VA. Advanced technology development for remote triage applications in bleeding combat casualties. US Army Med Dep J 2011;2:61-72.

\section{ABOUT THE AUTHORS}

\section{Aytekin Ünlü}

General Surgeon, GATA Genel Cerrahi AD Etlik, Ankara, Turkey

\section{Fatih Can}

Assistant Professor, Department of Surgery, GATA Genel Cerrahi AD Etlik, Ankara, Turkey

\section{Gokhan Yagci}

Associate Professor, Department of Surgery, GATA Genel Cerrahi AD Etlik, Ankara, Turkey

\section{Ismail Ozerhan}

Associate Professor, Department of Surgery, GATA Genel Cerrahi AD Etlik, Ankara, Turkey

\section{Juan A Asensio}

Professor, Department of Surgery, New York Medical College; Chief Trauma Surgery, Westchester University Medical Center, Valhalla NY, USA

\section{Patrizio Petrone (Corresponding Author)}

Chief, Research Coordinator, Trauma Surgery, Westchester University Medical Center, Valhalla, NY, USA, e-mail: patrizio.petrone@gmail.com 